\author{
Karolina Kwapisz \\ Uniwersytet Marii Curie-Skłodowskiej \\ kwapisz.k@gmail.com
}

\title{
TŁUMACZĄC ROBERTA FROSTA NA JĘZYK POLSKI
}

DOl: http://dx.doi.org/10.12775/RP.2019.015

Zarys treści: W niniejszym artykule podjęto próbę oceny, w jakim stopniu styl, idee i struktura utworu Roberta Frosta Acquainted with the Night zostały odzwierciedlone w polskich tłumaczeniach. W świetle tych rozważań, korzystając z metody kateny, przeprowadzono analizę oryginału przy szczególnym uwzględnieniu jego najważniejszych i ważnych cech. Następnie zbadano jego polskie przekłady (autorstwa Ludmiły Marjańskiej i Stanisława Barańczaka) oraz podjęto próbę oceny, w jakim stopniu zachowują one istotę, sensy i strukturę oryginalnego wiersza.

Słowa kluczowe: Robert Frost, katena, ocena tłumaczenia, Acquainted with the Night, Barańczak, Marjańska

\section{Wstęp}

Dobert Frost jest poetą doskonale znanym w Wielkiej Brytanii i Stanach RZjednoczonych, choć w naszym kraju ma wąskie grono miłośników. W Polsce nie znajdziemy jego wierszy na listach lektur (z wyjątkiem, oczywiście, list na kierunkach filologicznych związanych z kulturą i literaturą Stanów Zjednoczonych), mimo że jego utwory były wielokrotnie tłumaczone na język polski przez na przykład Juliusza Żuławskiego, Marka Skwarnickiego czy Stanisława Barańczaka ${ }^{1}$. Dorobek literacki Frosta, jak zauważa Leszek

1 Tłumaczenia wielu wierszy Frosta dokonane przez różnych tłumaczy znajdziemy w zbiorze opracowanym przez Leszka Elektorowicza (1972). Przekłady 55 wierszy poety dokonane przez Stanisława Barańczaka odnaleźć można w tomie Frost (1992). 
Elektorowicz (1972: 4-5), jest głęboko zakorzeniony w kulturze amerykańskiej, a pozorna prostota jego wierszy po wnikliwej lekturze otwiera przed czytelnikiem głębsze znaczenia. Warto zatem zbadać, w jakim stopniu polskie tłumaczenia tych utworów zachowują idee, sensy i struktury oryginałów - wszystko to, co sprawia, że Frost jest Frostem.

W dyskursie dotyczącym tłumaczeń problematyka mierzalności jakości przekładów jest często poruszanym zagadnieniem. Nie istnieje jeden wspólny sposób oceny tłumaczeń. Kryteria oceny będą różnić się od siebie w zależności od celu analizy czy struktury teoretycznej używanej przez krytyka (Schäffner 1997: 1). Według Juliane House (1997: 1) podstawą do zmierzenia jakości przekładu jest teoria przekładu (zob. Bukowski, Heydel 2009), stąd tak wiele różnych sposobów oceny. Według Eugena Nidy to reakcja czytelników jest najważniejszym elementem mierzenia jakości przekładów (zob. Nida 1964). Jeśli tłumaczenie jest zrozumiałe i przejrzyste dla jego odbiorców, może być ocenione jako dobre. John Catford był zwolennikiem ekwiwalentyzacji (zob. Catford 1965), w myśl której tekst źródłowy i tekst docelowy mają przekazywać to samo znaczenie i być względem siebie analogiczne. W celu zachowania ekwiwalentyzacji dopuszczalna jest zatem na przykład zmiana formy. Natomiast w ujęciu teorii „Skopos” zapoczątkowanej przez Katherinę Reiss i Hansa Vemeera tłumaczenie jest zabiegiem celowym, w którym intencja tłumacza jest czynnikiem najważniejszym (zob. Reiss, Vemeer 2014). Za cel tłumacz może uznać różne aspekty, na przykład wierność wobec oryginału lub koherentność w języku docelowym. Nurt opisowych badań nad przekładem, którego popularyzatorem był Gideon Toury, uznaje tekst oryginalny za podrzędny (zob. Toury 1995). Tłumaczenie ma obrazować cechy oryginału w sposób neutralny i jak najbardziej zbliżony do tekstów gatunkowo podobnych napisanych w języku docelowym - ma dobrze „wpasować się" w istniejący już w języku docelowym system literacki (zob. Even-Zohar 2009). Tymczasem Lawrence Venuti (1995) opowiada się „niewidzialnością” tłumacza, co oznacza, że tłumaczenie może być uznane za dobre, kiedy brzmi tak jakby od początku było napisane w języku docelowym (poprzez zastosowanie tzw. domestykacji). $\mathrm{Z}$ innej perspektywy na przekłady patrzą badacze, którzy rozpatrują tłumaczenia jako jeden z czynników kształtujących kulturę oraz uznają ją za ważny element wpływający na tworzenie i odbiór tłumaczeń (zob. Lefevere 2002).

Ocena kwintesencji utworu oraz tego, w jaki sposób została zachowana w tłumaczeniach, jest zatem zadaniem niełatwym. Dla każdego z badaczy twórczości wybranego autora tym, co stanowi jej istotę, może być inna cecha: na przykład struktura, obrazowanie czy język. Każdy krytyk musi wybrać po- 
dejście pozwalające mu na usystematyzowane i adekwatne ocenienie jakości przekładu. W próbie dokonania oceny oryginału i tłumaczenia przedstawionej w niniejszym artykule posłużę się metodą kateny, zaproponowaną przez Agatę Brajerską-Mazur. Myśl o stworzeniu tej metody zrodziła się w trakcie seminarium doktoranckiego profesora Stefana Sawickiego na KUL-u (Brajerska-Mazur 2012: 10), a inspiracją do jej stworzenia były prowadzone przez badaczkę prace nad oceną tłumaczeń dzieł Norwida. Metoda ta stoi w pewnej opozycji wobec dominanty semantycznej Barańczaka, która Brajerskiej-Mazur wydawała się zbyt subiektywna - dominanta uwzględnia jedynie osobiste odczucia jednego tłumacza wobec tego, co w danym utworze stanowi pewnego rodzaju „klucz” otwierający jego znaczenie. Aby uzyskać bardziej obiektywną podstawę analizy, Brajerska-Mazur (2005: 17) postanowiła zaadaptować do swoich badań pojęcie kateny. W tradycji kateny to komentarze do tekstów biblijnych sporządzone przez różnych pisarzy chrześcijańskich i zebrane w całość tworzącą swojego rodzaju łańcuch (łac. catanae - 'łańcuchy'). Ich celem było wyjaśnienie trudnych fragmentów Pisma Świętego. Według badaczki (2005: 17) podobną metodę można wykorzystać przy analizie przekładów: proponuje ona zebranie możliwie największej liczby istniejących interpretacji danego utworu, wyodrębnienie na ich podstawie jego najważniejszych (wyszczególnionych przez wszystkich lub większość badaczy) i ważnych (wymienianych przez znaczną część badaczy) cech oraz sprawdzenie, które $\mathrm{z}$ nich zostały zachowane w tłumaczeniach. Brajerska-Mazur argumentuje (2005: 17), że korzystając z tej metody, krytyk przekładu zyskuje szeroki i dogłębny wgląd w analizowany tekst, co pozwala na uniknięcie subiektywności. Dorota Malina zarzuca badaczce preskryptywizm (2014: 198) i podaje w wątpliwość samą metodę, zastanawiając się, czy przez wyciągnięcie wspólnego mianownika $\mathrm{z}$ interpretacji znanych badaczy rzeczywiście udaje się uzyskać „właściwszą dominantę niż w przypadku arbitralnego odczytania jednego tłumacza" (2014: 200). Stawia także pod znakiem zapytania kryteria dotyczące wyboru interpretatorów, których komentarze należy uwzględnić - czy warunkiem jest ich stopień naukowy, dorobek czy to, jak często się ich cytuje (Malina, 2014: 200). Brajerska-Mazur kontestuje jednak, że dzięki wykorzystaniu wielu istniejących analiz badacz przekładu rzeczywiście uzyska bardziej obiektywną dominantę, a czynnikami w doborze komentatorów są te wymienione przez Malinę, a także rozeznanie i wiedza w dziedzinie, którą się zajmują (Brajerska-Mazur 2014: 351). Metodologią mogącą pozwolić na uzupełnienie i dopracowanie metody stworzonej przez Brajerską-Mazur może być kognitywna metodologia badań literackich. Jak zaznacza Monika Linke (2009: 114), poprzez całościowe podejście do języka podejście kogni- 
tywne pozwala uwzględnić w ocenie tłumaczenia subiektywizm interpretacji, rolę metafor, czynniki kulturowe oraz relatywizm znaczenia. W tym ujęciu tłumaczony tekst jest swojego rodzaju „obrazem” lub „sceną” (Tabakowska 2001: 99), a zadaniem tłumacza jest sporządzenie kopii utworu w języku docelowym. Krytyk przekładu ocenia jakość tłumaczenia, a językoznawca jego adekwatność (Tabakowska 2015: 21). Stąd też według kognitywistów w analizie tłumaczenia nie chodzi o wytykanie błędów, lecz o pokazanie, jak niedostateczna dbałość o z pozoru nieważne szczegóły „w połączeniu z nieprzystawalnością konwencji gramatycznych w językach oryginału i przekładu" (Tabakowska 2015: 130) prowadzi do zmian w tekście przetłumaczonym. W kontekście niniejszych rozważań zatem o to, jak czynniki te wpływają na zmianę poezji Roberta Frosta w języku polskim względem jej oryginału. Linke podkreśla (2009: 114-115), że taka analiza pozwala na bardziej precyzyjną ocenę stopnia ekwiwalencji i uzasadnienie swoich osądów oraz jest pomocna w sprawdzeniu, w jakim stopniu potencjał znaczeniowy oryginału został zachowany lub utracony.

\section{Analiza oryginału}

Robert Frost - Acquainted with the Night (1964: 324)

I have been one acquainted with the night.

I have walked out in rain - and back in rain.

I have outwalked the furthest city light.

I have looked down the saddest city lane.

I have passed by the watchman on his beat

And dropped my eyes, unwilling to explain.

I have stood still and stopped the sound of feet

When far away an interrupted cry

Came over houses from another street,

But not to call me back or say good-bye;

And further still at an unearthly height,

One luminary clock against the sky

Proclaimed the time was neither wrong nor right.

I have been one acquainted with the night. 
Wiersz Acquainted with the Night został opublikowany po raz pierwszy w 1927 r. w „The Virginia Quarterly Review”, a rok później w tomie West-Running Book. Być może nie tak znany jak na przykład Mending Wall lub The Road not Taken, jest jednak na tyle charakterystyczny dla twórczości Frosta, że został odczytany przez Johna F. Kennedy'ego w trakcie pogrzebu poety (Bolton w: Dickstein 2010: 27).

Sonet ten to przykład tercyny, jednak z pewnymi zmianami wprowadzonymi przez autora. Richard J. Calhoun nazywa go „najbardziej odważnym i najbardziej znanym eksperymentem (Frosta) z formą sonetu" (2000: 231; tłum. moje - K.K.). W tradycji literackiej istnieją dwa podstawowe typy sonetów: włoski oraz angielski (nazywany także szekspirowskim). Sonet włoski zazwyczaj liczy osiem wersów wprowadzających i sześć wersów kończących, a podzielony jest na dwie części z układem rymów abba abba cde cde. Sonet angielski ma zwykle dwanaście wersów wprowadzających i dwa kończące, podzielone w obrębie czterech części (trzy czterowersowe i jeden dwuwersowy) z układem rymów abab cdcd efef gg. Calhoun klasyfikuje Acquainted with the Night jako sonet szekspirowski (2000: 226). Jednak już na pierwszy rzut oka widać, że w utworze tym Frost eksperymentuje z tradycyjną formą sonetu. Wiersz podzielony jest na cztery strofy trzywersowe i jedną dwuwersową. Pierwsze sześć wersów wprowadza, kolejne osiem rozwija ideę, a układ rymów prezentuje się następująco: aba bcb cdc dad aa. Tekst napisany jest pentametrem jambicznym, ale jak zauważa Keat Murray w linijce siódmej na chwilę zamienia się w spondej (2000: 378). W wersach od pierwszego do czwartego znaczenia zamykają się w jednej linijce, ale już od wersu piątego rozciągają się na dwie linijki. Taka budowa dodaje wierszowi dynamiczności i umacnia jego emocjonalny wydźwięk. Co więcej, ostatni wers utworu stanowi powtórzenie pierwszego, przez co utwór tworzy pętlę - po skończeniu jego lektury można ją płynnie rozpocząć na nowo.

Kolejnym ważnym elementem Acquainted with the Night jest zastosowanie czasu Present Perfect. Jego użycie sprawia, że czytelnik nie wie, kiedy dokładnie nastąpiły wydarzenia opisane w utworze: mogło to być kilka sekund wcześniej, kilka dni, lat itd., a niepewność ta wynika ze specyfiki zastosowania tego czasu w języku angielskim. Nie precyzuje on dokładnego momentu wykonywania danej czynności oraz nie potwierdza definitywnego zakończenia. Co więcej, czas ten został zastosowany w aż siedmiu wersach utworu, przy jednoczesnym stopniowym zmniejszeniu liczby jego występowania (Doyle 1965, cytowany w: Murray 2000: 378). W pierwszej strofie są to trzy użycia, w drugiej dwa, w trzeciej już tylko jedno. Potem, przez powtórzenie pierwszego wersu, zostaje on zastosowany w ostatniej linijce wiersza. $\mathrm{W}$ ten 
sam sposób użyty został także zaimek „ja”. Mimo tak wyraźnego zaznaczenia swojej osoby, podmiot liryczny rozpoczyna wiersz w tonacji bezosobowej. Osoba mówiąca w wierszu przyznaje: „I have been one acquainted with the night". Słowo one wprowadza do wiersza pewien dystans. Może ono świadczyć o uniwersalności lirycznego „Ja”: one oznacza po prostu „kogoś”. Z drugiej strony słowo to może akcentować wyobcowanie osoby mówiącej: one rozumiane jest wtedy jako ,jedyny”.

Podmiot liryczny poznaje noc - nie jest jej przedstawiony, nie oswaja jej, nie zaprzyjaźnia się z nią. Deirdre Fagan (2007: 22) zauważa, że użycie czasownika acquainted może oznaczać, że podmiot mówiący dopiero co poznał noc lub też zna już noc, ale jedynie powierzchownie. Murray (2000: 371) zaznacza, że acquainted komunikuje „poczucie zaznajomienia, rozpoznania oraz odrobinę obojętności, ale nie spoufalenie" (tłum. moje - K.K.). Użycie czasu Present Perfect może sugerować, że osoba mówiąca zamierza pogłębić tę nową znajomość. Podmiot liryczny spaceruje samotnie nocą, w ciemności, z dala od ludzi, spoglądając w głąb najsmutniejszej ulicy. Fagan (2007: 22) podkreśla, że w wierszu noc wydaje się nieodzownie połączona ze smutkiem, ale nie wiadomo, czy smutek jest odczuwany, czy jedynie obserwowany przez podmiot liryczny. Osoba mówiąca z jednej strony wydaje się unikać kontaktu z ludźmi: spotykając na drodze strażnika, nie chce mu nic wyjaśniać („And dropped my eyes, unwilling to explain”). W niechęci tej można doszukiwać się poczucia wstydu, jaki podmiot liryczny odczuwa w związku ze swoim nietypowym zachowaniem. Z drugiej jednak strony wydaje się rozczarowany, gdy usłyszany przerwany krzyk nie jest skierowany do niego.

$\mathrm{W}$ trzeciej strofie następuje w zachowaniu podmiotu mówiącego pewna zmiana. Im bardziej oddala się on od miasta, tym bardziej staje się świadomy. Obrazowanie w pierwszej części utworu skupia się nie na podmiocie lirycznym, ale na tym, co go otacza: ciemności, deszczu, ulicy, strażniku (Murray 2000: 376). Jednak gdy podmiot liryczny przystaje, może się wydawać, że zaskakuje go ustanie odgłosu kroków, co według Matthew J. Boltona (2010: 28) świadczy o tym, jak bardzo do tej pory osoba mówiąca była oddzielona nawet od własnego ciała. Od tego momentu podmiot liryczny staje się bardziej wrażliwy wobec swojego otoczenia. W ciemności dostrzega świetlisty zegar - nie wiadomo, czy jest to prawdziwy zegar (Perrine 1967: 91), czy też może księżyc (Wallace 1968: 121; Henry 1977: 29). Stanowi on dla lirycznego „Ja” pewny punkt orientacyjny, przez badaczy odczytywany jako symbol duchowego przewodnika (Little 2010: 206). Ten dwuwymiarowy symbolizm dotyczy nie tylko zegara, ale także strażnika, nocy i czasu (godziny). Noc staje się symbolem samotności, izolacji lub nawet depresji. Strażnik może być utożsamiany z Bogiem, którego istnienie 
i zdolność widzenia nawet tego, co niewidoczne dla ludzi, budzi w osobie mówiącej poczucie wstydu z powodu własnego zachowania. Godzina widoczna na zegarze przypomina czytelnikom o nieuniknionym upływie czasu.

Acquainted with the Night opowiada historię podmiotu lirycznego, który przechadza się nocą po ciemnych ulicach miasta. Chociaż doskwiera mu samotność, nie chce wchodzić w interakcję z napotkaną na swojej drodze osobą. Oprócz ciemności towarzyszy mu także smutek. Zasłyszany przerwany krzyk przypomina mu, że nikt na niego nie czeka, a w trakcie jego przechadzki nawet czas traci swoje znaczenie. Ten ponury obraz przynosi ze sobą przede wszystkim skojarzenia związane z depresją, na którą podmiot liryczny być może cierpi. W tak prostym obrazie Frost uchwyca aurę samotności i zagubienia, z czym niekiedy człowiek może się borykać. Po przeanalizowaniu istniejących komentarzy można wyodrębnić następujące najważniejsze cechy utworu:

1) aura samotności i odosobnienia widoczna w zachowaniu osoby mówiącej,

2) regularna i niezwykła budowa (eksperymentowanie ze strukturą sonetu),

oraz ważne cechy utworu:

3) różnica pomiędzy dwiema częściami liryku: pierwszą, wyrażającą wyobcowanie i dystans wobec samego siebie, i drugą, pokazującą coraz większą samoświadomość podmiotu lirycznego,

4) obrazowanie utworu i możliwość wielorakiej interpretacji płynąca z zawarcia w utworze czterech symbolicznych figur (noc, strażnik, zegar, czas).

\section{Analiza ttumaczeń}

Robert Frost - Którzy poznali noc (tłum. Ludmiła Marjańska w: Elektorowicz 1972: 100)

Ja jestem jednym $\mathrm{z}$ tych, co noc poznali.

Wyszedłem w deszcz, by w deszczu wracać znowu.

Doszedłem tam, gdzie latarń nikt nie pali.

Schodziłem w dół zaułków smutnych, schodów,

Minąłem też na straży wartownika

I opuściłem wzrok, niechętny słowu. 
I stałem cicho, stopą nie budząc chodnika,

Gdy ponad domy spłynął niespodzianie

Z innej ulicy krzyk i nie zanikał,

Ale nie wołał mnie ani był pożegnaniem.

A później znów w nieziemskiej tkwiąc oddali,

Świecący zegar na niebie to zdanie:

„Czas nie jest dobry ani zły”, zapalił.

Ja jestem jednym z tych, co noc poznali.

W swoim tłumaczeniu Ludmiła Marjańska zachowuje ogólną budowę utworu, nie zmieniając oryginalnego podziału wersów oraz przekładając pierwszy i ostatni wers $\mathrm{w}$ ten sam sposób, utrzymując tym samym poetycką pętlę. Tłumaczka oddaje także strukturę rymów, choć nie tak dokładnie jak Frost, na przykład: „znowu” - „schodów” - „słowu” (wersy 2, 4, 6). Przekład tytułu utworu sugeruje, że grupa ludzi poznała noc, a sam tytuł (w przeciwieństwie do oryginału) nie jest powtórzony w utworze, lecz zostaje nieco zmieniony: „(...) tych, co noc poznali”.

Warto zaznaczyć, że struktura gramatyczna wiersza jest bardzo trudna do oddania, ponieważ w języku polskim nie ma czasu gramatycznego, który by całkowicie odtwarzał formę i znaczenie angielskiego czasu Present Perfect - w przekładzie oddanego jako czas przeszły dokonany. Tłumaczka używa czasownika „poznać”, co nie zaburza prawdopodobieństwa pogłębienia relacji między podmiotem lirycznym a nocą. W tłumaczeniu zaimek „ja” (jako osobne słowo, a nie w formie użytych czasowników) pojawia się dwukrotnie (w wersach pierwszym i ostatnim). W języku polskim jego zastosowanie zawsze wiąże się z podkreśleniem osobistego punktu widzenia, dlatego też jego użycie w pierwszej linijce niweluje bezosobowy charakter wprowadzony w oryginale przez słowo one. Podmiot liryczny jest kimś, kto poznał noc, ale nie jest jedynym, lecz należy do grupy (najprawdopodobniej podobnych mu) ludzi. Nie wiemy, czy osoba mówiąca jedynie zapoznała się z nocą, czy też zdobyła głębszą wiedzę na jej temat, zrozumiała ją. Przechadza się po smutnych zaułkach (w liczbie mnogiej; może być to zinterpretowane jako nasycenie miasta smutkiem $\mathrm{w}$ większym stopniu niż w oryginale) i schodzi nieistniejącymi w oryginale schodami, co może dawać wrażenie jakby zapuszczał się jeszcze głębiej w ciemność. Kiedy spotyka strażnika, odwraca wzrok, ponieważ jest „niechętny słowu”. W wersji polskiej pojawia się tu zatem nieco odmienne i szersze znaczenie: u Frosta niechęć dotyczyła jedynie wyjaśnienia 
własnego zachowania, w przekładzie podmiot liryczny nie chce rozmawiać w ogóle. W ten sposób w tłumaczeniu zanika możliwość odnalezienia w tekście poczucia wstydu, jakie może wywoływać „nietypowe” zachowanie osoby mówiącej, a akcentowana jest jej niechęć do kontaktu z innymi.

Marjańska umiejętnie oddaje otaczającą liryczne „Ja” ciemność oraz jego izolację, czasami odchodząc od dosłownych znaczeń oryginału, lecz zachowując jego sens (na przykład tłumacząc wers "I have outwalked the furthest city line” jako „Doszedłem tam, gdzie latarń nikt nie pali”). Nie kreuje jednak wyraźnie obrazu podmiotu lirycznego, który zatrzymując się, staje się bardziej świadomy samego siebie i swojej sytuacji. Nie dziwi go odgłos własnych kroków, bo w tłumaczeniu zamiast usłyszeć swoje kroki, osoba mówiąca „stopą nie (budzi) chodnika”. Nacisk został tu więc położony nie na świadomość lirycznego "Ja", ale na otaczającą go zewsząd ciszę, której ten nie chce zaburzyć, a która jest bardzo mocno obecna w wersie Frosta („stood still”, „stopped sound"). Dodatkowo zasłyszany przez osobę mówiącą przerwany krzyk (oryg. an interrupted cry) w przekładzie zamienia się w nieprzerwany krzyk („Gdy ponad domy spłynął niespodzianie / Z innej ulicy krzyk i nie zanikał”), potęgując uczucie dziwności i grozy - bohater wiersza nie zatrzymuje się, żeby sprawdzić, skąd dobiega i co może być jego przyczyną, co w przypadku niezanikającego krzyku może wydawać się bardzo nieczułe. Tak jak u Frosta, wiersz kończy się dostrzeżeniem przez podmiot liryczny zegara, który nie pokazuje konkretnej godziny, a jedynie oznajmia, że czas nie jest „dobry ani zły”.

Robert Frost - Jest mi znajoma noc (tłum. Stanisław Barańczak w: Frost 1992: 147) Jest mi znajoma noc i jestem jej znajomy.

Przez jej deszczowe krople niosłem gołą głowę.

Szedłem poza najdalsze latarnie i domy.

Zaglądałem w zaułki wąskie i widmowe.

W świetle witryn mijałem się z nocnym strażnikiem

I wzrok spuszczałem, nie chcąc wdawać się w rozmowę.

Stawałem - echo kroków cichło nad chodnikiem -

Kiedy nad miejskie dachy z nagła i z daleka

Ktoś wyrzucał urwany krzyk - lecz nie był nikim,

Kto by mnie żegnał albo dawał znak, że czeka;

A dalej na tle nieba jaśniał nieruchomy

Zegar świetlny i z wyżyn nieziemskich orzekał, 
Że czas mnie wyznaczony nie jest mu wiadomy

Jest mi znajoma noc i jestem jej znajomy.

Stanisław Barańczak z niemalże chirurgiczną precyzją oddaje strukturę utworu, choć zdarza mu się użycie niepełnego rymu („strażnikiem” - „chodnikiem” - „nikim”). Tłumaczowi udaje się zachować podział stroficzny i wersowy wiersza, a także poetycką pętlę utworzoną przez tak samo brzmiące wersy pierwszy i ostatni, co oddaje poetycki kunszt Frosta.

Największe „przewinienia” tłumacza następują na poziomie obrazowania i znaczeń. Już w pierwszym wersie Barańczak stwarza pomiędzy nocą i podmiotem lirycznym wyraźnie wzajemną relację: podmiot liryczny poznaje noc, ale ona także go poznaje - czyli znaczenie, które nie istnieje u Frosta. Wers "Jest mi znajoma noc i jestem jej znajomy” sugeruje, że zapoznawanie już się odbyło. Barańczak interpretuje Present Perfect jako skutek tego, co już nastąpiło. "Jest mi znajoma noc" nie oddaje znaczenia „zapoznać się", ale sugeruje pewnego rodzaju poufałość, wiedzę na temat nocy, którą osoba mówiąca posiada. Liryczne "Ja" jest jedyne, ale niekoniecznie samotne, skoro ma z nocą wzajemną, bliższą relację. Jest także definitywne: podmiot liryczny nie należy do żadnej grupy, jest samotnikiem. Spogląda on nie na najsmutniejszą ulicę, ale na „zaułki wąskie i widmowe” - wydźwięk samotności i melancholii obecny w oryginale zostaje zatem zamieniony na poczucie tajemnicy i grozy. Samotność podmiotu lirycznego może umknąć uwadze czytelników, którzy mogą odnieść wrażenie, że osoba mówiąca przechadza się nocą w poszukiwaniu niewiadomego - bo przecież „zagląda” w liczne zaułki. Tak jak u Marjańskiej, nieobecna jest niechęć do wyjaśnień, a podmiot liryczny po prostu nie chce „wdawać się w rozmowę” ze strażnikiem.

Osoba mówiąca od początku utworu wydaje się świadoma swojego zachowania. Nie zaskakuje jej cisza, kiedy przystaje (a czasownik w formie „stawałem" sugeruje powtarzalność tej czynności), ustające echo kroków nie jest dla niej dziwne, lecz znajome, normalne, bo przecież słyszane już kilkukrotnie. „Urwany krzyk” przywodzi lirycznemu „Ja” myśli o kimś, kto mógłby go żegnać lub - czego nie ma w oryginale - czekać na niego. Taki przekład powoduje przeniesienie obrazowania samotności z pierwszej części wiersza, kiedy świadczy o niej otaczająca podmiot liryczny ciemność, smutek oraz jego izolacja, do części drugiej, kiedy przerwany krzyk wydaje się wyzwalać w nim tęsknotę za drugą osobą.

Największym odstąpieniem od znaczenia oryginału jest jednak przedostatni wers, w którym dowiadujemy się, że zegar informuje osobę mówiącą, że „czas mnie wyznaczony nie jest mu wiadomy”. U Frosta wskazywany czas 
jest ani odpowiedni, ani nieodpowiedni, ale czytelnik nie wie, wobec czego. W przekładzie Barańczaka poprzez wprowadzenie takiej zmiany może wydawać się, że podmiot liryczny myśli o własnej śmierci i przechadza się ulicami nocą w poszukiwaniu odpowiedzi na pytanie, ile czasu pozostało mu jeszcze na świecie. Jest to znaczenie, które może płynąć z utworu Frosta, lecz nie w tak dosadny i jednoznaczny sposób, jak w przekładzie Barańczaka - zmienia się zatem symbolika tekstu. Zmiana ta współgra z podejściem postulowanym przez Tabakowską, według której tłumacz powinien stworzyć najwierniejszą kopię oryginału, „ale także narzucić odbiorcy właściwą perspektywę, z której należy ten obraz oglądać” (Tabakowska 2015: 32). Jednocześnie poprzez taką ingerencję zatraca się dwuwymiarowość interpretacji symbolu zegara.

W swoich przekładach każdy z tłumaczy wprowadził do oryginału pewne zmiany. Marjańska i Barańczak zachowali w bardzo umiejętny sposób strukturę wiersza, jego wersyfikację i formę, w ich wersjach widoczne jest bowiem eksperymentowanie poety $\mathrm{z}$ tradycyjną formą sonetu. Obrazowanie aury samotności i ciemności wydaje się wierniej oddane u Marjańskiej, głównie dlatego, że do swojego tłumaczenia Barańczak dodaje pewne kwestie (jak na przykład bardziej zażyłą relację lirycznego „Ja” i nocy lub też poszukiwanie niewiadomego przez zaglądanie w zaułki). Obydwoje tłumaczy zachowało w utworze cztery figury (noc, strażnika, zegar i czas) bez naruszania możliwości ich symbolicznego odczytania. Warto jednak zaznaczyć, że u Barańczaka w dużym stopniu zmieniona została symbolika zegara: tak jak u Frosta nie wskazuje on dokładnej godziny, jednak informuje on podmiot liryczny o tym, że nieznany jest mu czas, który został lirycznemu „Ja" wyznaczony, a nie jedynie o tym, że czas nie jest ani dobry, ani zły. Tłumacze nie zachowali jednak w przekładzie różnicy między bezosobową i nieświadomą a świadomą i osobistą częścią utworu.

Nie jest łatwo porównać prezentowane przekłady, chociaż większe przewinienia w obrębie znaczeniowym można zarzucić Barańczakowi. Pod tym względem to wersja Marjańskiej wydaje się lepiej oddawać istotę wiersza. Uwzględniając cechy wymienione przy użyciu metody kateny, to właśnie tłumaczka odzwierciedla je w większym stopniu. Zachowała w przekładzie najważniejsze cechy utworu, czyli obecną $\mathrm{w}$ nim aurę samotności oraz jego budowę. W kwestii cech ważnych nie udało jej się utrzymać różnicy między dwoma częściami liryku (pierwsza wyraża wyobcowanie i bezosobowość, a druga pokazuje coraz większą samoświadomość podmiotu lirycznego), ale oddała jego obrazowanie. Poprzez wprowadzone w przekładzie zmiany Barańczakowi udało się dobrze zachować jedynie jego budowę i obra- 
zowanie związane $\mathrm{z}$ trzema $\mathrm{z}$ czterech obecnych $\mathrm{w}$ utworze symboli. Warto jednak zwrócić uwagę na to, że już od dawna badacze zauważają, że to rzeczy proste i klarowne są najtrudniejsze do przetłumaczenia, co w przypadku wierszy Roberta Frosta jest nie lada wyzwaniem, biorąc pod uwagę prostotę jego utworów, która po dogłębnej i uważnej lekturze okazuje się pozorna.

\section{Literatura}

Bolton M.J., 2010, Robert Frost, T.S. Eliot, and Modernist Poetics, [w:] Robert Frost, M. Dickstein (red.), Pasadena, s. 23-39.

Brajerska-Mazur A., 2005, Katena and Translations of Literary Masterpieces, „Babel”, nr 51(1), s. 16-30.

Brajerska-Mazur A., 2012, Wstęp. „Każdy przecież początek to tylko ciąg dalszy", [w:] A. Brajerska-Mazur, Filutka z filigranu paraduje w cudzym losie. Wisława Szymborska w anglojęzycznym przekładzie Stanisława Barańczaka i Clare Cavanagh, Lublin, s. 7-25.

Brajerska-Mazur A., 2014, Sprostowanie i odpowiedź na pytania recenzentki, „Przekładaniec”, nr 29, Kraków, s. 349-355.

Bukowski P., Heydel M. (red.), Współczesne teorie przekładu. Antologia, Kraków 2009.

Calhoun R.J., 2000, "By Pretending They Are Not Sonnets": The Sonnets of Robert Frost at the Millennium, [w:] Roads Not Taken: Rereading Robert Frost, W.E.J. Wilcox i J.N. Barron (red.), Columbia, s. 217-235.

Catford J., A Linguistic Theory Of Translation, Oxford 1965.

Elektrowicz L. (red.), 1972, Wiersze/Robert Frost, Warszawa.

Even-Zohar I., Miejsce literatury tłumaczonej w polisystemie literackim, tłum. M. Heydel, [w:] Współczesne teorie przekładu. Antologia, M. Heydel, P. Bukowski (red.), Kraków 2009, s. 195-204.

Fagan D.J., 2007, Critical Companion to Robert Frost: A Literary Reference to His Wife and Work, New York.

Frost R., 1964, Complete Poems of Robert Frost, New York, Chicago and San Francisco.

Frost R., 1992, 55 wierszy, tłum. S. Barańczak, Kraków.

Henry N., 1977, Frost's “Acquainted with the Night”, „The Explicator”, 35:3, Washington, s. 28-29.

House J., 1997, Translation Quality Assessment: A Model Revisited, Tübingen. 
House J., 2001, Translation Quality Assessment: Linguistic Description versus Social Evaluation, „Meta: Journal Des Traducteurs”, https://doi.org/10.7202/003141ar (dostęp: 24.04.19).

Lefevere A., Translation/history/culture: A sourcebook, London 2002.

Linke M., 2009, Kognitywne podejście do przekładu w kontekście współpracy interdyscyplinarnej - korzyści, wyzwania, perspektywy rozwoju, „Rocznik Przekładoznawczy. Studia nad teorią, praktyką i dydaktyką przekładu", 5, Toruń, s. 111-120.

Little M.R., 2010, Bloom's How to Write About Robert Frost, New York.

Malina D., 2014, Katena czy Dominanta, czyli jak amerykanizować Wisławę, „Przekładaniec”, 28, Kraków, s. 197-200.

Murray K., 2000, Robert Frost's Portrait of a Modern Mind: The Archetypal Resonance of Acquainted with the Night, „The Midwest Quarterly”, 41.4 (Summer 2000), Pittsburgh, s. 370-384.

Nida E., Toward a science of translating, Leiden 1964.

Perrine L., 1967, 50. Frost's Acquainted with the Night, „The Explicator”, 25:6, Washington, s. 90-91.

Reiss K., Vemeer H., Towards a general theory of translational action: Skopos theory explained, London 2014.

Schäffner C., 1997, From 'Good' to 'Functionally Appropriate': Assessing Translation Quality, „Current Issues In Language and Society”, 4(1), s. 1-5, https://doi.org/10.1080/13520529709615476 (dostęp:23.04.2019).

Tabakowska E., 2001, Językoznawstwo kognitywne a poetyka przekładu, tłum. A. Pokojska, Kraków.

Tabakowska E., 2015, Myśl językoznawcza z myślą o przekładzie. Wybór prac, P. de Bończa Bukowski, M. Heydel (red.), Kraków.

Toury G., Descriptive Translation Studies - and Beyond, Amsterdam 1995

Venuti L., Translator's Invisibility: A History of Translation, London 1995.

Wallace M., 1968, 64. Frost's Acquainted with the Night, „The Explicator”, 26:8, Washington, s. 121.

\section{Translating Robert Frost into Polish}

\section{Summary}

The aim of this paper is to discuss and evaluate to what extent the style, ideas and form of Robert Frost's poem "Acquainted with the Night" are reflected in the translation. With the use of the catena method, the author aims to distinguish the most important features of the original poem and then to assess if and how they were transferred 
to Polish versions (by Ludmiła Marjańska and Stanisław Barańczak). The analysis presented in this paper attempts to demonstrate whether the translators successfully reflected the ideas, meanings and structure of the original in their renditions.

Keywords: Robert Frost, catena, translation assessment, „Acquainted with the Night”, Barańczak, Marjańska

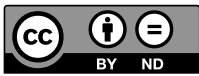

